\title{
Iris Marion Young
}

\section{Ideał wspólnoty i polityka różnicy ${ }^{1}$}

\section{Prolog}

Ideał wspólnoty stawia jedność ponad różnicę, bezpośredniość ponad mediację, współodczuwanie ponad uznanie ograniczeń własnego rozumienia innych $\mathrm{z}$ ich punktu widzenia. Wspólnota jest zrozumiałym marzeniem, wyrażającym pragnienie transparentnych dla siebie nawzajem jaźni, związków opartych na wzajemnej identyfikacji, społecznej bliskości i komforcie. Marzenie to jest zrozumiałe, ale politycznie problematyczne, gdyż ludzie nim motywowani będą próbować tłumić występujące pomiędzy nimi różnice lub domyślnie wykluczać ze swoich grup politycznych osoby, z którymi się nie identyfikują. Ponadto, promowana przez ten ideał wizja małych, opartych na relacjach twarzą w twarz, zdecentralizowanych grup, jest nierealistyczną wizją w warunkach polityki transformatywnej w masowych społeczeństwach miejskich.

Nie pisałam tego eseju wyłącznie $\mathrm{z}$ myślą o feministkach. Jednak zobowiązania i troski, które stały się dla niego motywacją, w dużym stopniu wypływają z moich doświadczeń wyniesionych $\mathrm{z}$ feministycznych grup i dyskusji. $\mathrm{Z}$ jednej strony, feministki były paradygmatycznymi głosicielkami krytykowanego przeze mnie ideału wspólnoty. Z drugiej strony, feministyczne dyskusje wokół konieczności uwzględniania różnic między kobietami, stanowią pierwotny polityczny impuls dla mojego dążenia do krytyki owego ideału.

Dominujące nurty feminizmu formułują ideał wspólnoty, który jest przeze mnie krytykowany, na dwóch poziomach. Po pierwsze, oczekiwałyśmy często od reprezentujących nas grup politycznych, aby spełniły nasze pragnienie wspólnoty w obronie przed alienacją $\mathrm{i}$ indywidualizmem, dominującymi w kapitalistycznym, patriarchalnym społeczeństwie. Dlatego szukałyśmy w naszych kręgach wzajemnej identyfikacji oraz uznania, traktując z nieufnością konflikt oraz pełen szacunku dystans. Miałyśmy zrozumiały powód, aby poszukiwać jedności i wzajemnej identyfikacji w obrębie owych grup. Dla większości z nas, feminizm był czymś więcej niż tylko polityką. Stanowił osobiste i duchowe poszukiwanie samowiedzy i kulturowej afirmacji. Jednak, dopóki grupami feministycznymi kierowało pragnienie bliskości i wzajemnej identyfikacji, nasza skuteczność polityczna była

\footnotetext{
${ }^{1}$ I. M. Young, The Ideal of Community and the Politics of Difference, [w:] Feminism/Postmodernism, red. L. Nicholson, New York 1990, s. 300-323 [przyp. thum.].
} 
www.praktykateoretyczna.pl

ograniczona. Dekonstrukcja, na której opieram swoją krytykę wspólnoty, pokazuje nam, że dążenie do dyskursywnej jedności lub całości stwarza granice, dychotomie i wykluczenia. Sugeruję, że pragnienie wzajemnej identyfikacji w ramach relacji społecznych w podobny sposób generuje wykluczenie. Kobieta, która ze względu na swoją rasę, klasę, kulturę czy seksualność nie może utożsamiać się z pozostałymi członkiniami - w feministycznej wspólnocie dążącej do wzajemnej identyfikacji - doświadcza podwójnego wykluczenia. Pragnienie wspólnoty w obrębie grup feministycznych przyczynia się do reprodukcji ich homogeniczności.

Po drugie, na bardziej ogólnym poziomie politycznej wizji, feministki nie rozwinęły modelu politycznej organizacji, który mógłby być alternatywą dla, z jednej strony, biurokracji grup interesów, z drugiej, dla małych, spersonalizowanych grup zadaniowych. Pomimo naszego krytycznego nastawienia do znacznej części męskiej tradycji teorii politycznej, wiele feministek bezkrytycznie przyjęło anarchistyczny komunitarianizm demokracji uczestniczącej jako wyraz naszej wizji idealnego społeczeństwa. W istocie wiele z nas zakładało, że kobiety i feministki mogą najpełniej zrealizować ten ideał, gdyż kobieca kultura jest mniej indywidualistyczna i w mniejszym stopniu oparta na konkurencji, niż męska. Ponadto uważałyśmy, że kobiety są, z psychologicznego i politycznego punktu widzenia, bardziej zorientowane na opiekuńczość i wzajemność. W tym eseju twierdzę, iż warunki nowoczesnego miejskiego społeczeństwa masowego wymagają stworzenia alternatywnej wizji nieopresyjnego społeczeństwa.

Poszukiwaną alternatywą jest polityka różnicy. Mimo iż logiczną i metafizyczną krytykę jedności wspólnoty wyprowadzam $\mathrm{z}$ filozofii postmodernistycznej, to, kreśląc konkretną polityczną wizję niewyczerpalnej heterogeniczności, w dużej mierze odnoszę się do feminizmu. Odbywające się w jego ramach dyskusje na temat opresyjnych implikacji wynikających z założenia jedności kobiet oraz wagi zajmowania się specyficznymi różnicami pomiędzy kobietami, zwiastują początki polityki wychodzącej poza wspólnotę. Uważam, że struktura polityczna i relacje społeczne, które rozwinęły się w ramach Stowarzyszenia Studiów Kobiecych ${ }^{2}$, stanowią przebłyski otwartości względem niezasymilowanej inności, którą w ostatniej części tego artykułu definiuję jako normę dla nieopresyjnego miasta.

\footnotetext{
${ }^{2}$ The National Women's Studies Association (NWSA) - założona w 1977 roku organizacja działająca na rzecz rozwoju i upowszechniania studiów kobiecych i gender studies. Więcej informacji na stronie internetowej organizacji: http://www.nwsa.org [przyp. tłum.].
} 


\section{Wstęp}

Radykalni teoretycy i aktywiści często odwołują się do ideału wspólnoty jako alternatywy dla opresji i eksploatacji, charakterystycznych, ich zdaniem, dla kapitalistycznego, patriarchalnego społeczeństwa. Zazwyczaj nie artykułują oni bezpośrednio znaczenia pojęcia wspólnoty, skupiając się raczej na nadaniu jej wartości emocjonalnej. Jeszcze rzadziej osoby przywołujące ideał wspólnoty jako alternatywy wobec kapitalistycznego, patriarchalnego społeczeństwa dociekają, co ów ideał zakłada lub implikuje, co konkretnie oznaczać miałoby ustanowienie społeczeństwa ucieleśniającego wspólnotę. Dlatego też stawiam wiele krytycznych pytań o znaczenie, założenia, implikacje i praktyczne zastosowanie ideału wspólnoty.

Jak w każdej teoretycznej refleksji, tak i tutaj nie mamy do czynienia z żadnym uniwersalnie podzielanym pojęciem wspólnoty, lecz z partykularnymi artykulacjami, które zachodzą na siebie lub uzupełniają się ${ }^{3}$. Będę opierać się na definicjach i wykładniach kilku autorów, których myśl stanowi przykład konceptualizacji wspólnoty jako politycznego ideału. Wszyscy oni podzielają krytykę liberalnej, indywidualistycznej ontologii społecznej. Większość uważa demokratyczny socjalizm za najlepszą zasadę społecznej organizacji. Moja analiza znajduje zastosowanie do tego ogólnego pola dyskursu politycznego, choć podejrzewam, że duża część zidentyfikowanej przeze mnie struktury pojęciowej może okazać się adekwatna w odniesieniu do ideału wspólnoty, przedstawianego przez bardziej konserwatywnych czy liberalnych myślicieli.

Podejmuję krytykę pojęcia wspólnoty zarówno na obszarze filozofii, jak i praktyki. Twierdzę, że ideał wspólnoty jest częścią tego, co Jacques Derrida nazywa metafizyką obecności, natomiast Theodor W. Adorno logiką tożsamości, metafizyką zaprzeczającą różnicy. Ideał wspólnoty zakłada istnienie podmiotów rozumiejących innych jak siebie samych, zaprzeczając tym samym istniejącej między nimi różnicy. Pragnienie wspólnoty opiera się na tym samym pragnieniu społecznej całości i identyfikacji, co rasizm, etniczny szowinizm, ale również polityczne sekciarstwo.

W stopniu, w jakim ideał wspólnoty pociagga za sobą podkreślanie wagi relacji twarzą twarz, oznacza również dewaluację $\mathrm{i}$ wyparcie różnicy $\mathrm{w}$ formie czasowego i

\footnotetext{
${ }^{3}$ Przedmiotem moich badań jest wspólnota jako normatywny ideał, który wskazuje, jak powinny być zorganizowane relacje społeczne. Istnieje wiele nienormatywnych użyć pojęcia wspólnoty, do których moje analizy nie mają zastosowania. Na przykład socjologowie zajmujący się badaniami nad wspólnotą, zazwyczaj używają tego terminu w sensie deskryptywnym jako określenia dla „małego miasta” lub „sasiedztwa”. Wątpliwości pojawiają się, gdy wspólnotę rozumiemy jedynie jako normatywny model społecznej organizacji.
} 
www.praktykateoretyczna.pl

przestrzennego zdystansowania. Ideał społeczeństwa składającego się ze zdecentralizowanych wspólnot opartych na bezpośrednich relacjach stanowi niepożądaną utopię z kilku powodów. Nie potrafi dostrzec, że alienacja i przemoc nie są jedynie funkcją zapośredniczenia relacji społecznych, ale mogą istnieć $\mathrm{i}$ istnieją także w kontaktach twarzą w twarz. Trudno w to uwierzyć, ale ideał ten proponuje nam społeczeństwo bez miasta. Nie jest także w stanie postawić ważnego politycznie pytania o relacje zachodzące pomiędzy postulowanymi przez siebie wspólnotami.

Ideał wspólnoty totalizuje i pozbawia wymiaru czasowego własną koncepcję życia społecznego poprzez ustanawianie opozycji między autentycznymi i nieautentycznymi relacjami społecznymi. Wymiaru czasowego pozbawione jest również jego rozumienie zmiany społecznej, pożądane społeczeństwo stanowi bowiem całkowitą negację tego, które istnieje obecnie. Ideał wspólnoty uniemożliwia zatem uchwycenie przejścia od tego, co zastane, do tego, co ma być, a co byłoby zakorzenione w zrozumieniu sprzeczności i możliwości istniejącego społeczeństwa.

Zamiast wspólnoty jako normatywnego ideału politycznej emancypacji, radykalni myśliciele powinni rozwijać koncepcje polityki różnicy. Model nieopresyjnego miasta oferuje ujmowanie związków społecznych jako pozbawionych dominacji. Umożliwiają one wspólne życie wśród obcych , z którymi nie tworzy się wspólnoty, ale stosunki z nimi opiera się na mediacji.

\section{Metafizyka obecności}

Zachodnie ujęcia, wyrażone zarówno w pismach filozoficznych, innych teoretycznych pracach, nierzadko również w mowie codziennej, ukazują to, co Derrida nazywa logiką tożsamości ${ }^{4}$. Owa metafizyka opiera się pragnieniu myślenia rzeczy w jedności,

\footnotetext{
${ }^{4}$ Tekstami, na których głównie się opieram są: J. Derrida, O gramatologii, tłum. B. Banasiak, Warszawa 1999; T. Adorno, Dialektyka negatywna, thum. K. Krzemieniowa, Warszawa 1986; J. Kristeva, Polylogue, Paris 1977; Tych troje autorów łączy sposób krytyki zachodniej metafizyki. Kilku autorów zwróciło uwagę na podobieństwa w tej kwestii między Adornem i Derrida. Zob. F. Dallmayr, Twilight of Subjectivity: Contributions to a Post-Structuralist Theory of Politics, Amherst 1981, s. 107-14, 127-36; oraz M. Ryan, Marxism and Deconstruction, Baltimore 1982, s. 73-81; dla wyjaśnień dotyczących paraleli między Kristevą i Adornem zob. D. Cornell, A. Thurschwell, Feminism, Negativity and Intersubjectivity, „Praxis International”, 1986, Vol. 5, No. 4, s. 484-504. Moje poglądy na temat metafizyki obecności oparte są na lekturze tych trojga autorów, jednak nie roszczę sobie prawa do „reprezentowania” ich myśli. Nie przywłaszczam sobie także tego, co mówią oni o teorii społecznej. Uważam, że zaprezentowana tu krytyka ideału wspólnoty swobodnie podąża ścieżkami wyznaczonymi przez dekonstrukcyjną krytykę Derridy, jednak nasze drogi rozchodzą się w kwestii postulowanej przeze mnie możliwości i konieczności zaproponowania alternatywnych konceptualizacji. Oczywiście stanowi to zawsze czynienie pewnych założeń, co wyklucza i tworzy granice, które jednak zawsze pozostają otwarte na możliwość dekonstrukcyjnej krytyki.
} 
formułowaniu reprezentacji całości, totalności. Dąży do jedności myślącego podmiotu z przedmiotem namysłu, zakładając, że przedmiot ten wiązał się będzie z uchwyceniem rzeczywistości. Pragnienie jedności zmusza do ujmowania wszystkiego, co jest, jako całości lub opisywania pewnych ontologicznych obszarów, takich jak życie społeczne, w kategoriach całości, systemu. Ponadto taka totalizacja nie musi być ograniczona do synchronicznej konceptualizacji. Teleologiczne ujmowanie procesu także ukazuje logikę tożsamości w stopniu, w jakim cel pojęciowo organizuje proces w jego jedności.

Pragnienie sprowadzenia rzeczy do jedności uruchamia logikę hierarchicznych opozycji. Każda próba zdefiniowania tożsamości, zamkniętej totalności, zawsze opiera się na wyłączeniu pewnych elementów, oddzieleniu tego, co czyste, od zanieczyszczonego. Na przykład, odnoszenie partykularnych rzeczy do uniwersalnej kategorii wymaga uznania pewnych cech jednostek za przypadkowe, zewnętrzne wobec esencji. Każda definicja czy kategoria tworzy rozróżnienie na wnętrze i zewnętrze, które logika tożsamości pragnie zachować w postaci jasno zakreślonej granicy. W historii myśli Zachodu metafizyka obecności stworzyła rozległą liczbę wzajemnie się wykluczających opozycji, które strukturyzują całą filozofię: podmiot/przedmiot, umysł/ciało, kultura/natura, mężczyzna/kobieta. W metafizycznej tradycji pierwszy człon opozycji jest wynoszony ponad drugi, oznaczający to, co chaotyczne, nieuformowane, zmienne. Myślenie metafizyczne tworzy podziały i formułuje sądy, opierające się na takich właśnie opozycjach, gdzie jedna strona odnosi się do tego, co czyste, autentyczne, dobre, a druga oznacza to, co brudne, nieautentyczne, złe.

Logika tożsamości dąży również do rozumienia podmiotu, osoby, jako toż-samej jedności. Począwszy od Kartezjusza, nowoczesna filozofia jest szczególnie zaabsorbowana jednością świadomości i jej bezpośrednią samo-obecnością. Tradycja filozofii transcendentalnej od Kartezjusza, przez Kanta do Husserla postrzega podmiot jako jedność i początek, toż-samy punkt wyjścia dla myśli i znaczenia, zawsze zdolny do uchwycenia sensu.

Istnieją dwa rodzaje krytyki metafizyki obecności, przeprowadzane przez Derridę, Adorna, Kristevą i innych. Pierwszy ukazuje wysiłki sprowadzenia rzeczy do jedności jako skazane na porażkę. Wysuwane przez metafizyków roszczenie totalności jest niespójne, gdyż, jak już wcześniej wspominałam, proces totalizowania sam usuwa pewne aspekty bytów. Niektóre doświadczane szczegóły odrzucane są jako niewyjaśniona, „akcydentalna” sfera, którą Derrida nazywa suplementem, a Adorno - addendum. Dążenie do stworzenia totalności, jak pokazuje logika hierarchicznych opozycji, skutkuje stworzeniem nie jednego, lecz dwóch: wnętrza i zewnętrza. Poszukiwanie tożsamości czy esencji zyskuje sens i czystość tylko 
www.praktykateoretyczna.pl

dzięki relacji do swego zewnętrza. To, co Derrida nazywa metodą dekonstrukcji, polega na pokazaniu, w jaki sposób pojęcie lub kategoria zawierają w sobie to, co rzekomo wykluczają. Oczywiście dialektyczna logika wysuwa podobne roszczenia. Jednak metoda dekonstrukcji lub to, co Adorno nazywa dialektyką negatywną, odrzuca Heglowską metodę dialektyczną. Heglowska dialektyka bowiem stanowi najwyższy przyrząd sumujący, doprowadzający opozycje generowane przez metafizyczną logikę do ostatecznej jedności w totalności.

Po drugie, metafizyka obecności wypiera lub zaprzecza różnicy. W kontekście owych filozoficznych rozważań pojęcie różnicy obfituje w wiele znaczeń. W moim ujęciu różnica oznacza nieredukowalną partykularność bytów, która uniemożliwia zredukowanie ich do powszechności czy sprowadzenie do wspólnego mianownika bez pozostawienia reszty. Owa partykularność wypływa z kontekstualności istnienia. Bycie rzeczy oraz to, co o niej orzekamy, stanowi funkcje jej kontekstualnych relacji $\mathrm{z}$ innymi rzeczami. Adorno w szczególności przeciwstawia logikę tożsamości partykularności bytów, którą wiąże także z ich materialnością. Według niego idealizm przejawiający logikę tożsamości unieważnia taką partykularność i konstruuje nierealne esencje ${ }^{5}$.

Derrida definiuje różnicę, używając przede wszystkim terminów odnoszących się do sposobu funkcjonowania języka, podkreślających jego nieredukowalną czasoprzestrzenność. Znak oznacza, posiada znaczenie dzięki miejscu zajmowanemu w łańcuchu znaków, poprzez odróżnianie się od innych znaków. Każdy moment oznaczania jednocześnie odracza, utrzymuje w zawieszeniu jakiekolwiek zamknięcie jego znaczenia. Każde wyrażanie charakteryzuje się mnogością znaczeń oraz możliwych do obrania kierunków jego interpretacji i rozwijania. Zdaniem Derridy metafizyka obecności próbuje pozbawić ów proces oznaczania jego wymiaru czasowego i przestrzennego, stwarzając iluzję czystego obecnego znaczenia, eliminującego relację referencji. Tym właśnie jest idealizm: ujmowaniem bytu i prawdy jako leżących poza czasem i zmianą ${ }^{6}$.

Kristeva, mimo iż częściej używa pojęcia „heterogeniczność”, to podobnie jak Derrida i Adorno, sugeruje, że logika tożsamości represjonuje heterogeniczność, którą autorka wiąże zarówno z ciałem, jak i z językiem. Ona także skupia się na języku i procesie oznaczania, ze szczególnym uwzględnieniem mówiącego podmiotu. Dla Kristevej podmiot nigdy nie jest jednością, zawsze stanowi proces, produkujący znaczenie poprzez grę między dosłownymi i

\footnotetext{
${ }^{5}$ T. Adorno, Dialektyka negatywna, s. 186-290.

${ }^{6}$ J. Derrida, O gramatologii, s. 21-140.
} 
przenośnymi, reprezentacyjnymi i muzycznymi aspektami, równocześnie obecnymi w mowie $^{7}$.

Podobnie jak Anthony Giddens czy Fred Dallmayr, uważam, że krytyka metafizyki obecności oraz postulat uwzględniania nieredukowalności różnicy mają poważne implikacje dla filozofii i teorii społecznej ${ }^{8}$. Twierdzę, iż ideał wspólnoty daje wyraz pragnieniu jedności, dostrzeżonemu przez wspomnianych autorów w metafizyce obecności. Wspólnota występuje zazwyczaj jako przeciwny biegun indywidualizmu, ale, jak to bywa z każdą opozycją, jedna jej strona określona zostaje w odniesieniu do drugiej. Uważam, że ideał wspólnoty wykazuje impuls totalizujący i zaprzecza różnicy na dwa zasadnicze sposoby. Po pierwsze, zaprzecza różnicy istniejącej wewnątrz podmiotu i pomiędzy podmiotami. Po drugie, uprzywilejowując bezpośrednie relacje, poszukuje modelu interakcji społecznych, który nie będzie zapośredniczony przez dystans czasowy i przestrzenny. Ponadto, poprzez radykalne przeciwstawienie nieautentycznych relacji w wyalienowanym społeczeństwie i autentycznych społecznych kontaktów w obrębie wspólnoty, pozbawia wymiaru czasowego proces społecznej zmiany, czyniąc ją statycznym ,przed” i „po” strukturze.

\section{Opozycja między indywidualizmem i wspólnotą}

Krytycy liberalizmu często przywołują koncepcję wspólnoty jako projekt alternatywny wobec przypisywanych mu indywidualizmu i abstrakcyjnego formalizmu ${ }^{9}$. Owa alternatywna ontologia społeczna odrzuca obraz osób jako oddzielonych i niezależnych atomów, obdarzonych takimi samymi formalnymi prawami, prawami do pozostawania w odseparowaniu względem innych. W ideale wspólnoty krytycy liberalizmu odnajdują ontologię społeczna, która atrybuty osoby ujmuje jako homologiczne względem społeczeństwa, w którym ona żyje.

Dla takich autorów ideał wspólnoty oznacza brak egoistycznej rywalizacji cechującej nowoczesne społeczeństwo. Krytycy liberalizmu odnajdują $\mathrm{w}$ nim alternatywę dla abstrakcyjnej, formalnej metodologii liberalizmu. Życie z innymi w takiej wspólnocie pociaga za sobą coś więcej, niż zwykłe respektowanie ich praw, implikuje bowiem uczestniczenie i podzielanie ich szczególnych potrzeb i interesów.

\footnotetext{
${ }^{7}$ J. Kristeva, Le Sujet en Procès, L'expérience et la Pratique, Matière, Sense, Dialectique, [w:] tejże, Polylogue, s. $55-136,263-86$.

${ }^{8}$ A. Giddens, Central Problems in Social Theory, Berkeley 1979, s. 28-40; F. Dallmayr, Twilight of Subjectivity..., s. 107-115.

${ }^{9}$ R. P. Wolff, The Poverty of Liberalism, Boston 1978, rozdz. V.
} 
www.praktykateoretyczna.pl

Na przykład Michael Sandel w swojej krytyce Rawlsa stwierdza, że podkreślany przez liberalizm prymat sprawiedliwości zakłada istnienie uprzedniej względem pragnień i celów jaźni, rozumianej jako jedność oraz oddzielona i odgraniczona całość. Uważa on, że jest to nierealna i niespójna koncepcja. Powinna ona zostać zastapiona przez konstytutywne ujęcie jaźni jako produktu tożsamości podzielanej z innymi, którzy jednocześnie wzajemnie się rozumieją i afirmują. Owa konstytutywna koncepcja jaźni jest wyrażana przez pojęcie wspólnoty.

W miare jak nasze konstytutywne pojmowanie samego siebie obejmuje podmiot szerszy od jednostki, czy to rodzinę, czy to plemię, miasto, klasę lub naród, odpowiednio do tego określa ono wspólnotę w konstytutywnym sensie. Wspólnotę tę wyznacza nie sam duch życzliwości, samo panowanie wartości komunitariańskich, czy nawet jakieś »wspólne ostateczne cele«, ale wspólne słownictwo dyskursu oraz dziedzictwo zrozumiałych bez słów praktyk, które redukują nieprzejrzystość uczestników, acz nigdy nie usuwają jej ostatecznie. O ile nadrzędność sprawiedliwości zależy od odrębności czy oddzielenia osób w sensie kognitywnym, jej prymat rozwiewa się w miarę jak nieprzejrzystość maleje, a wspólnota się pogłębia $^{10}$.

We współczesnej dyskusji politycznej, w większości przypadków ideał wspólnoty ujawnia się $\mathrm{W}$ powyższy sposób jako odpowiedź na indywidualizm, postrzegany w kategoriach dominującego poglądu teoretycznego oraz na alienację i fragmentację, ujmowanych jako powszechna kondycja społeczeństwa. Oznacza to, że wspólnota pojawia się jako element opozycji: indywidualizm/wspólnota, odseparowana jaźń/podzielana jaźń. W takiej dychotomii jedno pojęcie okazuje się być definiowane przez swoją negatywną relację do drugiego, a więc istnieje w logicznej od niego zależności. Według mnie owa opozycja jest jednak integralnym elementem nowoczesnej teorii politycznej, a nie alternatywą wobec niej.

W burżuazyjnej kulturze opozycja indywidualizm/wspólnota uzyskuje jeden ze swych wyrazów w przeciwstawieniu męskości i kobiecości. Kultura identyfikuje męskość z wartościami powiązanymi $\mathrm{z}$ indywidualizmem - samowystarczalnością, konkurencją, oddzieleniem, formalną równością praw. Natomiast kobiecość utożsamiana jest z wartościami bliskimi wspólnocie - afektywnymi relacjami opartymi na trosce, wzajemną pomocą oraz współpracą.

Carol Gilligan ujęła przeciwstawienie tego, co męskie i kobiece w terminach opozycji dwóch orientacji w moralnym rozumowaniu ${ }^{11}$. „Etyka praw”, którą Gilligan uważa za typową

\footnotetext{
${ }^{10}$ M. Sandel, Liberalizm a granice sprawiedliwości, tłum. A. Grobler, Warszawa 2009.

${ }^{11}$ C. Gilligan, In a Different Voice, Cambridge 1981.
} 
dla męskiego myślenia, uwypukla separację jaźni i znaczenie sprawiedliwych zasad gry, które mają pośredniczyć $\mathrm{w}$ ich rywalizacji. W przeciwieństwie do tego charakterystyczna dla kobiecego myślenia ,etyka troski” kładzie nacisk na istotność związków między jednostkami. Stanowi raczej etykę sympatii i wrażliwości na indywidualne potrzeby niż formalne mierzenie ich podług uniwersalnych zasad. Etyka troski wyraża relacyjność ideału wspólnoty, w przeciwieństwie do atomistycznego formalizmu liberalnego indywidualizmu.

Widzimy zatem, że opozycja indywidualizmu i wspólnoty jest homologiczna względem tego, co męskie/kobiece, publiczne/prywatne, wykalkulowane/uczuciowe, instrumentalne/estetyczne. Często sama implikuje owe rozróżnienia, obecne również w nowoczesnym myśleniu politycznym ${ }^{12}$. Myślenie takie, pozytywnie wartościując pierwsze kosztem drugich członów opozycji, umożliwia tym pierwszym dominującą z uwagi na kontekst instytucjonalny pozycję społeczną. Dlatego też postulowanie wyższości wspólnoty nad indywidualizmem, tego, co kobiece nad tym, co męskie, estetyki nad instrumentalnością, relacyjności nad rywalizacją, posiada pewien potencjał krytyczny względem dominującej ideologii i społecznych relacji. Jednak same te opozycje wyrastają i przynależą do kultury burżuazyjnej. $Z$ tego powodu zwykła zmiana wartościowania ich członów nie może stać się fundamentem dla autentycznej alternatywy wobec kapitalistycznego, patriarchalnego społeczeństwa.

Ponadto, jak większość takich opozycji, indywidualizm i wspólnota posiadają u podstaw swojej biegunowości tę samą logikę, która umożliwia ich wzajemne negatywne definiowanie. Każda ze stron opozycji pociaga za sobą zaprzeczenie różnicy oraz pragnienie sprowadzenia mnogości i heterogeniczności do jedności, choć stosuje w tym celu przeciwstawne strategie. Liberalny indywidualizm zaprzecza różnicy poprzez ujmowanie jaźni jako solidnej, samowystarczalnej jedności, niedefiniowanej przez lub w odniesieniu do kogokolwiek lub czegokolwiek poza nią samą. Jego formalistyczna etyka praw wypiera różnicę, sprowadzając wszystkie odseparowane jednostki do wspólnego mianownika praw. Z drugiej strony, wspólnota niweluje różnicę, uprzywilejowując jako społeczny ideał syntezę zamiast separacji. Zwolennicy wspólnoty uznają za podmiot społeczny stosunek jedności, tworzony poprzez identyfikację i symetrię pomiędzy jednostkami w obrębie całości. Jak ujmuje to Sandel, ludzka nieprzezroczystość ma tendencję do zanikania, kiedy cele, słownik i

\footnotetext{
${ }^{12}$ Bardziej szczegółowo omawiam implikacje tych opozycji dla nowoczesnej teorii i praktyki politycznej oraz przedstawiam praktyczną wizję ich zdemontowania w tekście Bezstronność i obywatelska sfera publiczna. Niektóre implikacje feministycznej krytyki teorii moralnej $i$ politycznej, tłum. J. Maciejczyk, http://www.ekologiasztuka.pl/pdf/f0087_iris_m_young.pdf [data dostęu: 22 lutego $2010 \mathrm{r}$.].
} 
www.praktykateoretyczna.pl

praktyki stają się identyczne. Obrazuje to chęć postrzegania zjednoczonych ze sobą osób w obrębie podzielanej całości.

Jak ma to miejsce $\mathrm{z}$ wieloma dychotomiami, tak i w tym wypadku możliwości społecznej ontologii oraz relacji społecznych zdają się wyczerpywać w ramach dwóch kategorii. Dla wielu autorów odrzucenie indywidualizmu logicznie pociąga za sobą wybór wspólnoty, i odwrotnie, brak przyjęcia wspólnoty ma oznaczać konieczność opowiedzenia się za indywidualizmem. W tych ramach dyskutowana jest choćby debata pomiędzy Elshtain i Ehrenreich $^{13}$. Na przykład Sara Evans i Harry Boyte twierdzą, że Ehrenreich promuje indywidualizm, ponieważ odrzuca ona odniesienia do wspólnoty czynione przez Elshtain ${ }^{14}$. Możliwość zaistnienia odmiennej koncepcji społecznej organizacji nie jest brana pod uwagę, gdyż wszystkie propozycje zostały zredukowane do wzajemnie wykluczających się kategorii indywidualizmu i wspólnoty.

Ostatecznie jednak dla najbardziej radykalnych teoretyków twarda opozycja indywidualizmu i wspólnoty załamuje się. W przeciwieństwie do reakcyjnych odwołań do wspólnoty, konsekwentnie kładących nacisk na podporządkowanie indywidualnych celów i wartości kolektywowi, najbardziej radykalni teoretycy twierdzą, że wspólnota jako taka opiera się na szacunku i realizacji indywidualnych celów oraz zdolności. Eleganckie rozróżnienie miedzy indywidualizmem i wspólnotą zaczyna generować dialektykę, w której stają się one swoimi wzajemnymi warunkami.

\section{Zaprzeczanie różnicy w obrębie i pomiędzy podmiotami}

W swojej interpretacji ontologii Marksa Carol Gould formułuje taką właśnie dialektyczną koncepcję wspólnoty jako przekroczenie syntezy tego, co społeczne i indywidualne. Owo idealne społeczeństwo przyszłości realizowane jest w postaci trzeciego stadium procesu społecznej ewolucji. Pierwszy etap stanowi życie we wspólnocie, w której jednostka podporządkowana jest kolektywowi, drugi spełniony jest przez indywidualistyczne społeczeństwo kapitalistycznej alienacji.

\footnotetext{
13 Chodzi tu o dyskusję odbywającą się na łamach magazynu „Dissent”, zapoczątkowaną przez artykuł Feminism, Family, and Community (1982) autorstwa Jean Bethke Elshtain. Stwierdza ona, że feminizm zbyt bezkrytyczne przyjął założenia indywidualizmu. Określając siebie jako „społeczną feministkę”, zauważa, że zobowiązania wobec innych znajdują swój pierwotny wyraz w rodzinie. Dla Ehrenreich natomiast priorytetem jest prawo do jednostkowej godności, a rodzina jawi się jako miejsce kapitalistyczne opresji. Elshtain przeciwstawiała się definiowaniu rodziny wyłącznie w kategoriach ekonomicznych [przyp. tłum.].

${ }^{14}$ H. C. Boyte, S. M. Evans, Strategies in Search of America: Cultural Radicalism, Populism, and Democratic Culture, ,Socialist Review” 1984, May to August, s. 73-100.
} 
Oddzielone podmioty, które wchodzą ze sobą tylko w relacje przedmiotowe, mianowicie jako byty dla innych, teraz rozpoznają siebie $w$ tych przedmiotach lub uznają te przedmioty jako podobne sobie. Dlatego uznają siebie nawzajem jako podmioty, a jedność między podmiotami i przedmiotami zostaje w owym akcie uznania ustanowiona na nowo. Podmioty nie są ze sobą połączone wówczas jako zewnętrzni obcy, lecz na zasadzie wspólnego gatunkowo podmiotu. Relacje są zatem wewnętrzne, stanowią wzajemne powiązania w obrębie wspólnego lub wspólnotowego podmiotu, którego nie tworzą już odrębne jednostki w związkach zewnętrznych, lecz raczej indywidua zjednoczone we wspólnej podmiotowości [...]. Podmioty są współzależne, a relacje między nimi są wewnętrzne, gdyż każdy podmiot zyskuje kształt poprzez swoje relacje z innym i bycie rozpoznanym przezeń jako podmiot. Dlatego też jednostki te tworzą wspólny, ale zróżnicowany podmiot, który wyraża siebie w i poprzez każdą z nich. Ponownie konstytuowana w tych wewnętrznych relacjach całość lub jedność jest mediowana lub wyróżniona przez ich indywidualność, ale jednoczona przez ich wspólność ${ }^{15}$.

Według Derridy, dialektyczna logika tłumi różnicę nie poprzez podporządkowanie wielości prostej zasadzie uniwersalnej, lecz przez domknięcie procesu eksterioryzacji. Owo zamknięcie ujawnia się w pojęciu całości lub totalności, w obrębie której opozycje, różnice mają zostać pogodzone i zrównoważone ${ }^{16}$. Jak wiele innych ekspresji ideału wspólnoty, koncepcja Gould pracuje na i poprzez totalizujące pragnienie pogodzenia różnic między podmiotami.

Ideał komunitariański mieści się w ramach metafizyki obecności, ponieważ przyjmuje, że podmioty nie muszą być już względem siebie zewnętrzne. Nie muszą już wzajemnie siebie prześcigać w kierunkach, których wzajemnie nie podzielają i nie akceptują. Ponadto ideał rozszerza tę wzajemność na koncepcję dobrego społeczeństwa, rozumianego jako telos, koniec konfliktu i przemocy w ludzkich interakcjach. Wspólnota ujmowana jest tutaj jako totalność na dwa sposoby. Nie posiada ontologicznego zewnętrza, gdyż realizuje jedność woli powszechnej i indywidualnej podmiotowości. Nie posiada również historycznego zewnętrza, gdyż nie przewiduje dalszych etapów rozwoju.

Seyla Benhabib, mimo iż nie przedstawia swojego ideału wspólnoty, formułuje podobny ideał osoby połączonej z innymi poprzez obustronne rozpoznanie podmiotowości. Traktuje go jako partykularny punkt wyjścia dla moralnej autonomii. Liberalizm utrzymuje koncepcję moralnej autonomii („punkt widzenia uogólnionego innego”), która abstrahuje od różnicy, pragnień i uczuć pomiędzy osobami, sprowadzając wszystko do podzielania wspólnego zestawu formalnych praw i obowiązków. W przeciwieństwie do tego, ,punkt

\footnotetext{
${ }^{15}$ C. Gould, Marx's Social Ontology, Cambridge 1978, s. 9.

${ }^{16}$ M. Ryan, Marxism and Deconstruction, Baltimore 1982, s. 65-71.
} 
www.praktykateoretyczna.pl

widzenia konkretnego innego", zdaniem Benhabib, ujmuje każdą osobę w jej konkretnej indywidualności.

Zakładając ten punkt widzenia, abstrahujemy od tego, co nadaje ciagłość naszej wspólności i dążymy do zrozumienia innego tak, jak on/a sam/a rozumie siebie. Próbujemy ująć potrzeby innego, ich motywacje, to, czego poszukuje i pragnie. Nasza relacja wobec innego jest ustrukturowana przez normę dopełniającej się wzajemności: każdy jest upoważniony oczekiwać od innych takich sposobów zachowania, które gwarantują innemu poczucie uznania i potwierdzenia jako konkretna, indywidualna istota o specyficznych potrzebach, talentach, możliwościach. W tym wypadku nasze różnice nie wykluczają się, lecz dopełniają ${ }^{17}$.

Stworzona przez Benhabib kategoria punktu widzenia konkretnego innego wyraża ideał wspólnoty jako wzajemnego rozumienia się osób, połączonych z sobą wewnętrznie, jak ujmuje to Gould, a nie zewnętrznie. Wielu autorów podziela ten ideał łączenia się z innymi osobami wewnętrznie, rozumienia innych $\mathrm{z}$ ich punktu widzenia. W poprzednio cytowanym fragmencie Sandel, mając na uwadze wspólnotowy ideał, postuluje eliminację nieprzejrzystości innych. Isaac Balbus stawia za cel radykalnej polityki i ustanowienia wspólnoty, przekroczenie ,inności” innego na drodze wzajemnego uznania ${ }^{18}$. Roberto Unger ujmuje ideał wspólnoty jako polityczną alternatywę wobec osobistej miłości. We wspólnocie osoby wchodzą ze sobą w relacje jako konkretne jednostki, które rozpoznają siebie w innych, gdyż wyznają wspólne cele. Konflikt między wymaganiami indywidualności oraz uspołecznienia zanika we wzajemnej sympatii ${ }^{19}$. Dorothy Allison proponuje feministkom ideał wspólnoty, który scharakteryzowany jest jako: „podzielane uczucie przynależności i połączenia” wraz z ,ekstatycznym poczuciem pojedynczości”20.

Wszystkie te sformułowania dążą do rozumienia wspólnoty jako unifikacji konkretnych osób poprzez podzielanie podmiotowości: osoby przestaną być nieprzejrzyste, inne, niezrozumiałe, stając się zamiast tego połączonymi, współodczuwającymi, rozumiejącymi innych jak siebie samych jednostkami. Taki ideał podzielanej subiektywności, lub inaczej, wzajemnej przezroczystości podmiotów, zaprzecza różnicy w sensie podstawowej asymetrii między podmiotami. Zgodnie z odkryciem Hegla, pogłębionym przez analizy

\footnotetext{
${ }^{17}$ S. Benhabib, Communicative Ethics and Moral Autonomy - referat wygłoszony na zjeździe Amerykańskiego Stowarzyszenia Filozoficznego [American Philosophical Association] w grudniu 1982. Zob. S. Benhabib, The Generalized and Concrete Other: Toward a Feminist Critique of Substitutionalist Universalism, „Praxis International", 1986, Vol. 5, No. 4., s. 402-424.

${ }^{18}$ I. Balbus, Marxism and Domination, Princeton 1983.

${ }^{19}$ R. M. Unger, Knowledge and Politics, New York 1975, s. 220-222.

${ }^{20}$ D. Alison, Weaving the Web of Community, „Quest: A Feminist Quaterly” 1978, Vol. 4, s. 79.
} 
Sartre’a, osoby wykraczają poza siebie z konieczności, gdyż podmiotowość to negatywność. Spojrzenie innego na mnie jest zawsze uprzedmiotowiające. Inne osoby nigdy nie postrzegają świata z mojej perspektywy, jestem zawsze skonfrontowana z takim doświadczeniem siebie, które nie pokrywa się z obiektywnym ujęciem mojego ciała, działań i słów przez innego.

Oczywiście ta obustronna intersubiektywna transcendencja umożliwia podzielanie doświadczenia między jednostkami, na co Hegel kładł nacisk w większym stopniu niż Sartre. Owo podzielanie jednak nigdy nie jest całkowitym obustronnym zrozumieniem i wzajemnością. Ponadto podzielanie okazuje się kruche. Inna osoba w następnym momencie może już inaczej niż ja sama rozumieć moje słowa lub wyciagać z moich działań konsekwencje, które będą sprzeczne z moimi intencjami. Ta sama różnica, która umożliwia podzielanie poglądów między podmiotami, sprawia również, iż nieporozumienie, odrzucenie, wycofanie czy konflikt są zawsze możliwymi do zaistnienia warunkami społecznego bycia.

Pogląd głoszący, że każda osoba może zrozumieć inną tak, jak rozumie samą siebie, co więcej, że osoby mogą poznać inne podmioty $w$ ich konkretnych potrzebach i pragnieniach, zakłada, iż podmiot może poznać samego siebie i wyrazić ową wiedzę w sposób adekwatny i jednoznaczny dla innych. Taka koncepcja samowiedzy utrzymuje kartezjańskie rozumienie podmiotowości, będące podstawą dla nowoczesnej metafizyki obecności. Idea jaźni jako ujednoliconego podmiotu pragnień i potrzeb, będąca źródłem twierdzeń i działań, został poważnie poddany w wątpliwość przez wielu współczesnych filozofów ${ }^{21}$. W tym kontekście będę bazować na moim odczytaniu myśli Julii Kristevej.

Bez wikłania się w językowe szczegóły konstytuujące jej pojęcie podmiotu w procesie, spróbuję ogólnie przedstawić stojący za nim zamysł. Kristeva opiera się na psychoanalitycznym pojęciu tego, co nieświadome, aby podkreślić, że podmiotowość jest heterogeniczna i zdecentralizowana. Świadomość, znaczenie, intencja są możliwe tylko dzięki temu, że podmiot w procesie wymyka się i przekracza swoje intencje i znaczenia. Przykładowo, każde wyrażenie posiada nie tylko dosłowne znaczenie, ale obarczone jest także dwuznacznościami, ucieleśnionymi w gestach, tonie głosu i rytmie, które łącznie wpływają na niezamierzoną heterogeniczność jego znaczenia. Dzieje się tak, gdy mamy do czynienia z działaniami i interakcjami z innymi ludźmi. To, co mówię i robię, zawsze posiada wielość znaczeń, niejasności gier, które często okazują się niespójne ${ }^{22}$.

\footnotetext{
${ }^{21}$ Sandel w książce Liberalizm a granice sprawiedliwości formułuje silną krytykę Rawlsa, twierdząc, że jego teoria sprawiedliwości zakłada, iż jaźń jest uprzednia i oddzielona od działań, które podejmuje jako ich spójne źródło. Sandel w szeregu argumentów pokazuje niespójność tak ujętej koncepcji jaźni.

${ }^{22}$ J. Kristeva, Le Sujet en Proces..., s. 55-106.
} 
www.praktykateoretyczna.pl

Skoro podmiot nie stanowi jedności, nie może być dla siebie obecnym i znanym. Nie zawsze wiem, co mam na myśli, czego potrzebuję, chcę, pragnę, gdyż nic z tego nie wypływa źródłowo z jakiegoś ego. Często wyrażam moje pragnienia gestem lub tonem głosu, bez intencji uczynienia tego. Świadomość, mowa, ekspresywność możliwe są tylko wtedy, gdy podmiot nieustannie przekracza siebie, i co za tym idzie, jest z konieczności niezdolny do zrozumienia samego siebie. Podmioty zawsze posiadają wiele niespójnych pragnień; nadają przedmiotom kolejne warstwy znaczeń, nie będąc świadomymi poszczególnych warstw i związków między nimi. W konsekwencji każdy indywidualny podmiot stanowi grę różnic, które nie mogą zostać uchwycone w spójną całość.

Skoro podmiot jest heterogenicznym procesem, niemogącym uobecnić się sobie, oznacza to, że podmioty nie mogą również stawać się transparentnymi i całkowicie obecnymi dla siebie nawzajem. Jeśli żaden podmiot nie jest w stanie pojać sam siebie, i z tego powodu nie może w pełni wyrazić swoich potrzeb i pragnień, to tym bardziej wymyka się opartemu na współodczuwaniu rozumieniu przez innych. Nie mogę rozumieć innej osoby tak, jak ona rozumie samą siebie, gdyż ona sama nie może całkowicie siebie zrozumieć. W rzeczywistości, biorąc pod uwagę, że wypowiedzi danej osoby mogą wykraczać poza jej świadomość i intencje, mam szansę zrozumieć pewne ich aspekty lepiej niż podmiot je wyrażający.

Gould odwołuje się do takiego ideału wspólnej podmiotowości jako alternatywy względem utowarowienia osób, charakterystycznego, jej zdaniem, dla kapitalistycznej dominacji. Sugeruje, że owa dominacja może zostać wyeliminowana tylko jeśli osoby rozumieją siebie nawzajem, „wewnętrznie”. Oczywiście nie przeczę, że obecne relacje społeczne są oparte na dominacji i eksploatacji, jednak pojmowanie tych warunków w terminach niemożliwego ideału podzielanej subiektywności może odwracać uwagę od bardziej konkretnych analiz sposobów ich eliminacji.

Ten ideał podzielanej podmiotowości jest nie tylko niemożliwy, ale wiąże się także z niepożądanymi implikacjami politycznymi. Według mnie zarówno teoretycy polityczni, jak i działacze nie powinni podchodzić z zaufaniem do pragnienia obustronnego rozpoznania i identyfikacji z innymi, gdyż bezpośrednio zaprzecza to różnicy poprzez utrudnianie darzenia szacunkiem osób, z którymi się nie utożsamiamy. Twierdzę, że dążenie do obustronnego rozumienia i wzajemności, fundujących ideał wspólnoty, jest bliskie pragnieniu identyfikacji, które leży u podstaw rasowego i etnicznego szowinizmu.

W mowie potocznej, dla większości osób w Stanach Zjednoczonych pojęcie wspólnoty odnosi się do ludzi, z którymi identyfikują się lokalnie. Oznacza sąsiedztwo, 
kościół, szkołę. Niesie z sobą także konotacje z etnicznością lub rasą. Dla większości osób w Stanach Zjednoczonych w stopniu, w jakim w ogóle uznają siebie za członków wspólnoty, stanowi ona grupę, która podziela konkretne dziedzictwo, tożsamość, kulturę i zestaw norm. Współcześnie deklarowanie członkostwa w takiej wspólnocie często okazuje się połączone z opozycyjnym odróżnianiem się od innych grup, które są w najlepszym wypadku dewaluowane. Ludzie identyfikują się tylko z wybranymi innymi, czują się społecznością jedynie z niektórymi, natomiast boją się różnicy, z jaką inni ,inni” każą im się konfrontować, gdyż identyfikują się z odmienną kulturą, historią oraz światopoglądem.

Uważam, że rasizm, etniczny szowinizm i klasowe dewaluowanie wyrastają częściowo z pragnienia wspólnoty, czyli chęci zrozumienia innych tak dobrze, jak my i oni rozumiemy samych siebie. W praktyce takie wzajemne zrozumienie może zostać osiągnięte tylko w obrębie homogenicznej grupy, która zdefiniowana jest poprzez wspólne cechy. Jednak taka wspólna identyfikacja pociaga za sobą odniesienie również do tych, którzy zostali z niej wykluczeni ${ }^{23}$. W dynamice współczesnego amerykańskiego rasizmu i szowinizmu etnicznego, pozytywne wartościowanie jednej grupy osiagane jest poprzez definiowanie innych grup jako tworzonych przez podludzi. Nie twierdzę oczywiście, że ideał wspólnoty sam w sobie jest rasistowski. Chcę jednak podkreślić, że odwołania do ideału wspólnoty w kontekście rasistowskiego i szowinistycznego społeczeństwa mogą umacniać właśnie te jego aspekty.

Ponadto dążenie do wzajemnej identyfikacji i zrozumienia wśród tych, którzy chcą tworzyć radykalną i postępową politykę, mogło i nieraz doprowadzało do zaprzeczenia lub stłumienia różnic wewnątrz politycznych grup i ruchów. Na przykład wiele grup feministycznych dążyło do stworzenia relacji równości i wzajemnego zrozumienia poprzez ujmowanie każdej niezgody, różnicy czy odchylenia jako nadwerężenia więzi siostrzeństwa, destrukcję osobistych relacji i wspólnoty. Często w obrębie grup kobiecych występowała silna presja podzielania sposobu rozumienia świata, stylu życia, a także spory nacisk na równe przydzielanie zadań oraz rotację przywództwa. Owa presja prowadziła nieraz do homogenizacji grupy, a nawet całego ruchu - pierwotnie heteroseksualnego, lesbijskiego, białego lub akademickiego ${ }^{24}$. W ostatnich latach feministki, być może w stopniu

\footnotetext{
${ }^{23}$ Krytyka dialektycznego rozumu Sartre'a jest klasyczną pracą na temat tak pojmowanej dynamiki włączania i wykluczania. Innym przykładem konkretnie odnoszącym się do wykluczających aspektów tworzenia wspólnot jest: R. Moss Kantner, Commitment and Community: Communes and Utopias in Sociological Perspective, Cambridge 1972, s. 52-53.

${ }^{24}$ F. Rainone, Community, Politics and Spirituality - referat zaprezentowany na konferencji o feminizmie i psychologii (Boston, luty 1984); J. Sawicki, Foucault and Feminism: Towards a Politics of Difference,
} 
www.praktykateoretyczna.pl

poważniejszym niż jakakolwiek inna postępowa grupa polityczna, dyskutowały sposoby uczynienia swojego ruchu bardziej heterogenicznym i wrażliwym na różnicę. Niestety, nieustanne pragnienie wzajemnej identyfikacji utrudnia wprowadzenie w życie postulowanej heterogeniczności.

W rasistowskim, seksistowskim i homofobicznym społeczeństwie, które gardzi i dewaluuje pewne grupy, koniecznym i pożądanym dla członków owych grup jest wewnętrzne solidaryzowanie się i celebrowanie wspólnej kultury, dziedzictwa i doświadczeń. Jednak nawet $\mathrm{w}$ obrębie takich separatystycznych ruchów zbyt silne pragnienie jedności może prowadzić do represjonowania różnicy w obrębie danej grupy, na przykład wyłączania lesbijek i gejów z grup czarnoskórych nacjonalistów lub feministek ze wspólnot rdzennych Amerykanów itd.

Wiele innych radykalnych organizacji politycznych i ruchów ufundowanych jest na podobnym dążeniu do wspólnoty. Zbyt często członkowie grup politycznych obierają za swój cel wzajemną przyjaźń. W związku z tym zaczynają postrzegać ową grupę jako wybrakowaną, gdy nie udaje im się osiagnąc oczekiwanego poziomu uwspólnienia ${ }^{25}$. Takie pragnienie wspólnoty często kieruje energię na cele odmienne od politycznych oraz tworzy atmosferę elitarności, która nie pozwala rozrastać się grupie, odtrącając potencjalnych członków. Bardziej pożądana polityka zaakceptuje fakt, że członkowie organizacji nie rozumieja pozostałych jak siebie samych, oraz uzna ten dystans bez przekształcania go w wykluczenie.

\section{Zaprzeczenie różnicy jako czasowe i przestrzenne dystansowanie}

Wielu teoretyków polityki, forsujących ideał wspólnoty, za zasadnicze dla jego realizacji uznaje istniejące $\mathrm{w}$ małych grupach relacje typu twarzą w twarz. Peter Manicas proponuje wizję wspólnoty ufundowanej na takich właśnie bezpośrednich relacjach.

Rozważmy przykład stowarzyszenia, w którym osoby pozostają w kontakcie twarzą w twarz, a ich relacje nie są mediowane przez »autorytety«, uświęcone zasady, zreifikowane biurokracje lub towary. Każdy jest gotowy przyjąć postawy, rozumowania i pomysły innych. Ich relacje są więc otwarte, niezapośredniczone i oparte na wzajemności. Ponadto całościowe warunki ich życia społecznego są

\footnotetext{
„Hypatia: a Journal of Feminist Philosophy” 1986, Vol. 1. No. 2, s. 23-36. Zob. A. Lorde, Sister Outsider, Trumansburg 1984 .

${ }^{25}$ Wini Breines dokumentuje owo dążenie do wzajemnej przyjaźni oraz związane z nim rozczarowania na przykładzie ruchu studenckiego w latach sześćdziesiątych: W. Breines, Community and Organization in the New Left: 1962-68, South Hadley 1982, szczególnie rozdz. IV.
} 
wspólnie określane, gdyż każdy posiada równy głos i taką samą władzę. Jeśli warunki te są spełnione, a konsekwencje oraz owoce ich powiązanych i niezależnych działań są dostrzegane i świadomie stają się przedmiotem indywidualnego pragnienia i starań, wówczas mamy do czynienia z demokratyczną wspólnotą ${ }^{26}$.

Roberto Unger twierdzi, iż wspólnota wymaga relacji twarzą w twarz zachodzących w wielu kontekstach. Aby rozumieć innych ludzi i być rozumianym przez nich w naszej wyjątkowości, nie możemy jedynie wspólnie pracować - powinniśmy razem bawić się, wychowywać dzieci, wspólnie przeżywać smutki, itd. ${ }^{27}$. Christian Bay określa dobre społeczeństwo jako ufundowane na małych wspólnotach bezpośredniej demokracji i wielostronnych interakcji ${ }^{28}$. Michael Taylor precyzuje, że we wspólnocie relacje między członkami/członkiniami muszą być bezpośrednie i wielostronne. Podobnie jak Manicas, podkreśla, że więzi możemy uznać za bezpośrednie tylko wtedy, gdy nie są one zapośredniczone przez jakichkolwiek reprezentantów, liderów, biurokratów, instytucje państwowe czy kodeksy ${ }^{29}$. Chociaż Gould nie określa relacji twarzą w twarz jako koniecznych, niektóre elementy stosowanego przez nią języka sugerują, że wspólnota może się realizować jedynie na ich bazie. Według niej w instytucjonalizacji demokratycznego socjalizmu

związki społeczne stają się niezapośredniczonymi, wzajemnymi, podmiotowymi relacjami pomiędzy jednostkami. Więzi te, ponownie osobiste na wzór tych ze stadium przedkapitalistycznego, przestają być relacjami dominacji mediowanymi przez zewnętrzne obiekty, jak w drugim okresie ${ }^{30}$.

Dostrzegam szereg problemów w uprzywilejowaniu przez teoretyków wspólnoty relacji twarzą $\mathrm{w}$ twarz. Zakładają oni iluzoryczny ideał niezapośredniczonych relacji społecznych oraz błędnie utożsamiają mediację z alienacją. Oznacza to negowanie różnicy w znaczeniu dystansu czasowego i przestrzennego. Ponadto implikują model dobrego społeczeństwa jako składającego się ze zdecentralizowanych, małych jednostek, model nierealistyczny i politycznie niepożądany zarazem. Poza tym unikają politycznie istotnego pytania o relacje w kontekście zdecentralizowanych wspólnot.

\footnotetext{
${ }^{26}$ P. Manicas, The Death of the State, New York 1974, s. 247.

${ }^{27}$ R. M. Unger, Knowledge and Politics..., s. 262-263.

${ }^{28}$ Ch. Bay, Strategies of Political Emancipation, South Bend 1981, rozdz. V i VI.

${ }^{29}$ M. Taylor, Community, Anarchy and Liberty, Cambridge 1982, s. 27-28.

${ }^{30}$ C. Gould, Marx's Social Ontology..., s. 26.
} 
www.praktykateoretyczna.pl

Wszyscy powyżej cytowani autorzy nadają prymat obecności twarzą w twarz, gdyż twierdzą, że jedynie w takich warunkach relacje społeczne mogą być bezpośrednie. W moim odczytaniu mianem bezpośrednich relacji społecznych obdarzają oni szereg różnych rzeczy. Są one bezpośrednie, osobiste, umożliwiają zrozumienie osoby w jej indywidualności. Stanowi to rozszerzenie ideału wzajemnego zrozumienia, który poddałam krytyce $\mathrm{w}$ poprzednim fragmencie. Bezpośredniość oznacza tu również relacje współ-obecności, w których osoby doświadczają jednoczesności mówienia i słyszenia, przebywają w tej samej przestrzeni, dosłownie rzecz biorąc: na wyciągnięcie ręki ${ }^{31}$.

Jednak ideał niezapośredniczonej współobecności podmiotów stanowi metafizyczną iluzję. Nawet relacje twarzą w twarz między dwoma osobami mediowane są przez głos i gest, przestrzenność i czasowość. W momencie dołączenia do interakcji trzeciej osoby relacje między pozostałymi uczestnikami stają się dodatkowo zapośredniczone przez jej obecność. Mediacja relacji między osobami przez mowę, działanie i obecność innych osób stanowi fundamentalny warunek życia społecznego. Bogactwo, kreatywność, różnorodność oraz potencjał społeczeństwa rozszerza się wraz ze wzrostem zakresu i sposobów zapośredniczeń, łączących osoby pomimo dystansu czasowego i przestrzennego. Jednak im większy ów dystans, tym więcej ludzi zapośrednicza relacje między poszczególnymi osobami.

Normatywne uprzywilejowanie relacji twarzą w twarz, charakterystyczne dla omawianego ideału wspólnoty, dąży do stłumienia różnicy $\mathrm{w}$ sensie czasowego i przestrzennego dystansowania $\mathrm{w}$ ramach procesów społecznych, które potęgowane są i ułatwiane właśnie przez materialne media. Taki ideał dematerializuje własną koncepcję interakcji i instytucji. A przecież wszystkie społeczne interakcje dokonują się w czasie i w ramach pewnej przestrzeni. Społeczne pragnienie polega na dążeniu do przenoszenia znaczenia, działania i jego efektów poza określony moment i dane miejsce. Jako pracujące podmioty oddzielamy moment produkcji od czasu konsumpcji. Nawet społeczeństwa ograniczone do określonego terytorium z niewieloma instytucjami i małą populacją wynajdują środki umożliwiające jego członkom komunikację pomimo dystansu. Wyszukują sposoby na utrzymanie relacji społecznych, nawet jeśli nie zachodzą one twarzą w twarz. Społeczeństwa zasiedlają coraz większe obszary i coraz bardziej różnicują swoje działania w

\footnotetext{
${ }^{31}$ Derrida podejmuje kwestię iluzorycznego charakteru ideału niezapośredniczonej obecności podmiotów dla siebie nawzajem w swoim omówieniu prac Lévi-Straussa i Rousseau. Zob. J. Derrida, O gramatologii, s. 147195.
} 
przestrzeni, czasie, funkcji. Proces ten ulega przyspieszeniu i przybiera jakościowo specyficzną formę w nowoczesnych społeczeństwach industrialnych ${ }^{32}$.

Twierdzę, że nie ma żadnych podstaw teoretycznych do tego, by uznawać relacje twarzą w twarz za bardziej czyste, autentyczne niż relacje społeczne zapośredniczone czasowo i przestrzennie. Zarówno interakcje zachodzące, jak i te niezawiązywane twarzą w twarz, stanowią relacje zapośredniczone i w obu przypadkach istnieje możliwość pojawienia się separacji i przemocy, ale także komunikacji i konsensu. Moim zdaniem teoretycy wspólnoty mają skłonność do nadawania szczególnego znaczenia relacjom twarzą w twarz, ponieważ błędnie identyfikują mediację z alienacją.

Przez alienację rozumiem sytuację, w której osoby nie mają kontroli nad swoimi działaniami, nad warunkami lub konsekwencjami owych działań w efekcie interwencji innych podmiotów $^{33}$. W tym sensie społeczna mediacja stwarza warunki możliwości zaistnienia alienacji; zapośredniczenia stwarzają okazję do interwencji zarówno pomiędzy warunkami a działaniem podmiotu, jak i działaniem a jego konsekwencjami. W ten sposób umożliwiają dominację i wyzysk. W nowoczesnych społeczeństwach zasadniczymi strukturami prowadzącymi do alienacji i dominacji są biurokracja oraz utowarowienie wszelkich aspektów ludzkiej aktywności, szczególnie pracy. Oba zjawiska opierają się na złożonych strukturach zapośredniczeń pomiędzy dużą liczbą osób.

Mediacja jest koniecznym warunkiem alienacji, jednak nie pociaga to za sobą odwrotnej implikacji: jakoby poprzez eliminację struktury zapośredniczeń można było usunąć alienację. Skoro czasowe i przestrzenne zdystansowanie jest fundamentalne dla procesów społecznych oraz osoby zawsze mediują między sobą w celu stworzenia sieci społecznych, to społeczeństwo oparte na bezpośredniości jest niemożliwe. Choć mediacja może być koniecznym warunkiem alienacji, nie jest warunkiem wystarczającym. Alienacja stanowi specyficzny rodzaj zapośredniczenia, w którym działania jednych służą celom innych bez wzajemności i otwartości, co wymaga przymusu i dominacji.

Stawiając za ideał społeczeństwo niezapośredniczonych relacji twarzą $\mathrm{w}$ twarz, teoretycy wspólnoty generują dychotomię pomiędzy „autentycznym” społeczeństwem przyszłości a „nieautentycznym” społeczeństwem, w którym żyjemy, określanym wyłącznie

\footnotetext{
${ }^{32}$ A. Giddens, Central Problems In Social Theory..., s. 198-233.

33 Przydatne wyjaśnienia dotyczące alienacji znaleźć można w: R. Schmitt, Alienation and Class, Cambridge 1983, szczególnie w rozdz. V. W książce tej Schmitt, jak wielu innych autorów, których cytowałam, ujmuje wspólnotę jako miejsce negacji wyalienowanego społeczeństwa. Jednak w przeciwieństwie do autorów przywoływanych w tej części nie przyjmuje on jako jej warunku relacji twarzą w twarz. Mimo tego wyartykułowana tu krytyka ma zastosowanie do jego koncepcji wspólnoty w stopniu, w jakim przeprowadza dystynkcję czyste/nieczyste oraz wyraża pragnienie jedności, które krytykowałam wcześniej.
} 
www.praktykateoretyczna.pl

przez alienację, biurokratyzacje i degradację. Jednak tworzenie takiej opozycji pozbawia nasze rozumienie zmiany społecznej wymiaru czasowego. Zgodnie z tym ujęciem zmiana społeczna i rewolucja oznaczają całkowitą negację obecnego stanu społeczeństwa i ustanowienie prawdziwie dobrego społeczeństwa. Gould w swoim schemacie społecznej ewolucji definiuje „społeczeństwo przyszłości” poprzez negację i odcięcie się od społeczeństwa kapitalistycznego. W tym kontekście historia przestaje być procesem zachodzącym w czasie, lecz ufundowana zostaje na podziale na dwie statyczne struktury: „przed” wyalienowanego społeczeństwa i „po” wspólnoty.

Projekcja ideału wspólnoty jako radykalnego innego współczesnego społeczeństwa zaprzecza różnicy $\mathrm{w}$ aspekcie sprzeczności i ambiwalencji życia społecznego. Zamiast dychotomizowania tego, co czyste i nieczyste w postaci dwóch stadiów historii lub dwóch rodzajów relacji społecznych, wyzwalająca polityka powinna ujmować proces społeczny w wielości jego działań i struktur, które wzajemnie się dopełniają jak i wchodzą w sprzeczność, będąc podstawą wyzysku, ale i emancypacji. Polaryzacja między nieczystym, nieautentycznym społeczeństwem współczesnym oraz czystym i autentycznym, do którego dążymy, detemporalizuje proces zmiany, gdyż nie jest w stanie wyartykułować przejścia od pierwszego do drugiego. Jeśli zmiana instytucjonalna miałaby być w ogóle możliwa, powinna rozpocząc się od interwencji w sprzeczności i napięcia istniejącego społeczeństwa. Co więcej, nie istnieje żaden telos ostatecznego społeczeństwa; ujęcie społeczeństwa jako ruchomego i pełnego sprzeczności procesu oznacza, że zmiana na lepsze jest zawsze możliwa i konieczna. Postawienie wymogu, aby autentyczna wspólnota ucieleśniała relacje twarzą w twarz modelem dobrego społeczeństwa niesie ze sobą specyficzną wizję społecznej organizacji. Jeśli od idealnej wspólnoty oczekujemy, aby relacje między jej członkami były bezpośrednie i wielostronne, to oparte na tym ideale społeczeństwo musi składać się z małych grup, w których wszyscy znają się osobiście. Dla większości autorów oznacza to zdecentralizowany charakter idealnej organizacji społecznej, z drobnym przemysłem i lokalnymi rynkami. Każda wspólnota dąży wówczas do ekonomicznej samowystarczalności, każda demokratycznie decyduje o organizacji czasu pracy i odpoczynku.

Nie wątpię w atrakcyjność małych grup, w których jednostki nawiązują osobiste relacje, a ich interakcje cechuje mnogość kontekstów. Podobnie jak życie z innymi w jednym domu, tak i funkcjonowanie we wspólnotach wzajemnej przyjaźni odznacza się specyficznie ludzkimi wartościami, takimi jak ciepło i współdzielenie. Ponadto nie ma wątpliwości, że patriarchalne społeczeństwo kapitalistyczne niszczy wspólnoty oparte na wzajemnej przyjaźni, tak jak atomizuje rodziny. Z pewnością w naszej wizji dobrego społeczeństwa 
chcielibyśmy uwzględnić instytucjonalne warunki, które umożliwiałyby kultywowanie doświadczenia wzajemnej przyjaźni, generowanego we względnie małych grupach wchodzących w interakcje w bogatych kontekstach. Jednak uznanie wartości owych relacji twarzą w twarz jest czymś zupełnie różnym od proponowania ich jako zasady organizującej całe społeczeństwo.

Model dobrego społeczeństwa ufundowany na zdecentralizowanych, ekonomicznie samowystarczalnych, opartych na bezpośrednich relacjach wspólnotach, które funkcjonują jako autonomiczne polityczne byty, jest równie utopijny, co niepożądany. Powołanie go do życia wymagałoby pozbawienia nowoczesnego społeczeństwa jego miejskiego charakteru, gigantycznego, fizycznego przearanżowania przestrzeni życiowej, miejsc pracy i obszarów handlu. Model przekształconego, lepszego społeczeństwa musi w pewnym konkretnym sensie rozpoczynać od określonych materialnych struktur, istniejących $\mathrm{w}$ danym momencie historii, co w przypadku Stanów Zjednoczonych oznacza wielki przemysł i ośrodki miejskie. Model społeczeństwa złożonego z małych wspólnot nie jest dla wielu tym najbardziej upragnionym. Jeśli poważnie potraktujemy sposób, w jaki współcześnie żyje wielu ludzi, okaże się, iż lubią oni miasta, rozumiane jako miejsca spotkania z obcymi.

Musimy zmierzyć się $\mathrm{z}$ jeszcze jednym problemem wynikającym $\mathrm{z}$ przyjęcia omawianego tu ideału za polityczny cel. Artykułowany w ten sposób model dobrego społeczeństwa nie stawia pytania o sposób wzajemnego powiązania małych wspólnot wchodzących w jego skład. Ideał ów zakłada często samowystarczalność i decentralizację, sugerujące istnienie nielicznych, poza przyjacielskimi wizytami, relacji pomiędzy zdecentralizowanymi wspólnotami. Jednak nierealnym jest zakładać, że takie zbiorowości nie mają potrzeby wchodzenia w rozległe, zewnętrzne relacje wymiany zasobów, dóbr, elementów kultury. Nawet jeśli zaakceptujemy twierdzenie, że radykalna przebudowa społeczeństwa w kierunku jego bardziej sprawiedliwej i humanitarnej wersji wymaga życia w małych, demokratycznie zorganizowanych jednostkach pracy i sąsiedztwa, nie oznacza to, iż podjęliśmy istotne politycznie pytanie: w jaki sposób miałyby być zorganizowane relacje między tymi wspólnotami, aby zapewnić sprawiedliwość i zapobiec dominacji? Kiedy podejmiemy to kluczowe polityczne pytanie, ponownie ujawni się filozoficzna i praktyczna waga mediacji. Po raz kolejny polityka musi być pojmowana jako związek obcych, którzy nie rozumieją siebie nawzajem (w subiektywnym i bezpośrednim sensie) oraz nawiązują relacje mediowane przez czas i miejsce. 
www.praktykateoretyczna.pl

\section{Życie miejskie i polityka różnicy}

Jak już uprzednio stwierdziłam, radykalna polityka musi wychodzić od tego, co dane historycznie. Nie może postrzegać przy tym zmiany jako negacji owych danych, lecz raczej tworzenie czegoś dobrego z wielości ich elementów. Miasto jako bardzo zaludniony obszar, wraz z wielkim przemysłem i miejscami masowych zgromadzeń, stanowi naszą historycznie daną rzeczywistość, zatem radykalna polityka za punkt wyjścia musi przyjąć nowoczesne życie miejskie. Dostępne nam materialne otoczenie oraz struktury definiują i zakładają związki miejskie. Znaczne rozmiary populacji tak w naszym, jak i w innych społeczeństwach, oraz poczucie narodowej lub etnicznej tożsamości nawiązywane $\mathrm{z}$ milionami ludzi potwierdzają wniosek, że wizja demontażu idei miasta jest beznadziejnie utopijna.

Przyjęcie za punkt wyjścia danego nam nowoczesnego życia miejskiego jest nie tylko konieczne, ale i pożądane. Nawet dla wielu z tych, którzy potępiają alienację, umasowienie i biurokratyzację w patriarchalnym społeczeństwie kapitalistycznym, życie miejskie jest jak magnes. Nowoczesna literatura, sztuka i film sławiły życie miejskie, jego energię, kulturowe zróżnicowanie, technologiczną złożoność, wielość form aktywności. Nawet najbardziej zagorzali rzecznicy zdecentralizowanej wspólnoty uwielbiają oprowadzać odwiedzających ich przyjaciół po Bostonie, San Francisco, czy Nowym Jorku, wspinając się na wieże, by obserwować błysk świateł i kosztując potraw w najlepszych etnicznych restauracjach. Wielu ludziom uważanym za odmieńców w małych wspólnotach, z których pochodzą - czy będą to „niezależne” kobiety, socjaliści, geje, czy lesbijki - to właśnie miasto oferuje gościnną anonimowość i pewien zakres wolności ${ }^{34}$. Oczywiście emancypacyjne możliwości kapitalistycznych metropolii obfitują w niejednoznaczności.

Mimo to za punkt wyjścia w tworzeniu alternatywnej (wobec ideału wspólnoty) wizji dobrego społeczeństwa proponuję obranie naszego pozytywnego doświadczenia życia miejskiego. Naszym politycznym ideałem jest nieopresyjne miasto. Kreśląc ten ideał, przyjęłam kilka materialnych przesłanek. Będziemy zakładać poziom wydajności w społeczeństwie, który odpowiada na potrzeby wszystkich, oraz oczyszczenie i renowację fizycznego miejskiego środowiska. Przyjmujemy, że wszyscy pracujący wykonują pracę mającą znaczenie, a ci, którzy nie mogą pracować, mają zapewnione godne utrzymanie.

\footnotetext{
${ }^{34}$ Marshall Berman prezentuje fascynujące ujęcie uroków życia miejskiego w książce Wszystko, co stałe, rozplywa się w powietrzu: rzecz o doświadczeniu nowoczesności (tłum. M. Szuster, Kraków 2006). George Shulman wskazuje na otwartą skończoność życia miejskiego, przeciwstawiając ją pastoralnej wizji wspólnoty w The Pastorall Idyll of Democracy, „Democracy” 1983, Vol. 3, s. 43-54. Z podobną krytyką mamy również do czynienia w: D. Plotke, Democracy, Modernization, and Democracy, „Socialist Review” 1984, Vol. 14, March to April, s. 31-56.
} 
Zarysowując taki ideał życia miejskiego, zależy mi na opisie miasta jako pewnego rodzaju związków pomiędzy ludźmi, ich historiami, historiami innych. Zatem przez „miasto” rozumiem nie tylko wielkie metropolie, które zazwyczaj nazywamy miastami (cities) w Stanach Zjednoczonych. Rodzaj opisywanych przeze mnie więzi występuje również w miejscowościach, które określilibyśmy mianem miasteczek (towns), w których żyje dziesięć czy dwadzieścia tysięcy osób.

Jako proces nawiązywania relacji między ludźmi, życie miejskie ucieleśnia różnicę we wszystkich sensach przywoływanych przeze mnie w tym tekście. Miasto w sposób oczywisty uwydatnia czasowe i przestrzenne dystansowanie oraz dyferencjację, które, jak próbowałam pokazać, ideał wspólnoty doprowadza do rozkładu. Oblicze miejskiego środowiska tworzą jego własna historia oraz historie zamieszkujących je jednostek i grup. Taka fizyczna historyczność, jak i funkcje oraz grupy występujące w mieście w różnych okresach czasu, tworzą jego przestrzenne zróżnicowanie. Miasto jako sieć i zbiór miejsc rozumianych jako osobne, na przykład poszczególnych budynków, parków, sąsiedztw, a także jako fizyczne środowisko daje możliwość zmian i zaskakuje, gdy jedno miejsce przechodzi w drugie.

Czasowe i przestrzenne zróżnicowanie, cechujące fizyczne środowisko miasta, produkuje doświadczenie estetycznej niewyczerpalności. Budynki, skwery, kręte ulice i alejki oferują niewyczerpany zasób indywidualnych przestrzeni i przedmiotów, charakteryzujących się unikalną estetyką. Zestawienie obok siebie niedopasowanych stylów i funkcji, po dłuższym czasie wyłaniające się w granicach miasta, współtworzy ową specyficzną przyjemność i zaskakuje. To jest właśnie doświadczenie różnicy w sensie, który zawsze był w nią wpisany. Nowoczesne miasto nie jest otoczone murami; nie jest zaplanowane ani spójne. Zamieszkiwanie miasta oznacza nieustanne poczucie istnienia czegoś poza, świadomość, że dziejące się w tych miejscach życie wykracza poza moje doświadczenie, że nigdy nie mogę uchwycić miasta w jego całości.

Dlatego też życie miejskie ucieleśnia różnicę, w przeciwieństwie do ideału bezpośrednich relacji wyrażanego w większości koncepcji wspólnoty. Życie miejskie to współistnienie obcych. Nieznający się ludzie spotykają się, twarzą w twarz lub za pośrednictwem mediów, często pozostając dla siebie obcymi, uznającymi jednak bliskość i swój wzajemny wkład w egzystencję. W takich spotkaniach ludzie nie są „wewnętrznie” połączeni, jak chcieliby teoretycy wspólnoty, ani nie rozumieją każdego z jego własnej perspektywy. Są powiązani zewnętrznie, doświadczają każdego jako innego, różnego, pochodzącego z odmiennej grupy, posiadającego własną historię, zawód, kulturę, których nie rozumieją. 
www.praktykateoretyczna.pl

Przestrzenie publiczne miasta stanowią jednocześnie wyraz totalności relacji życia miejskiego, jak i pierwotnego sposobu ich nawiązywania i doświadczania. Przestrzeń publiczna jest miejscem dostępnym dla każdego, w którym ludzie angażują się w działania jednostkowe lub w małych grupach. W przestrzeni publicznej ludzie są świadomi swojej wzajemnej obecności, a nawet czasem aktywnie w tym współistnieniu uczestniczą. W mieście mamy do czynienia z wielością takich miejsc: ulice, restauracje, sale koncertowe, parki. Tutaj mieszkańcy w swej różnorodności zbierają się, zamieszkują tuż obok, czasami doceniają siebie nawzajem, wspólnie się bawią lub po prostu rozmawiaja, by zawsze, rozchodząc się, pozostawać obcymi. Właśnie taki charakter mają współcześnie parki miejskie.

Życie miejskie implikuje społeczną niewyczerpalność, w przeciwieństwie do ideału wspólnoty opartej na bezpośrednich relacjach, gdzie mamy do czynienia ze wzajemnym zrozumieniem, grupową identyfikacją i lojalnością. Miasto opiera się na ogromnym bogactwie ludzi i grup (wielości subkultur, zróżnicowaniem ich działań i funkcji), których życia i ruchy mieszają i nakładają się w przestrzeniach publicznych. Ludzie przynależą do odrębnych grup i kultur, wchodzą w interakcje w sąsiedztwie i miejscach pracy. Przekraczają jednak to, co najbardziej lokalne w stronę publicznych przestrzeni rozrywki, konsumpcji, polityki. Stają się świadkami funkcjonowania odmiennych kultur w publicznych interakcjach bez przyjmowania ich za własne. Na przykład docenianie kuchni etnicznych czy profesjonalnych muzyków opiera się na uznaniu, że przekraczają one bliski im świat życia codziennego.

W mieście obcy żyją obok siebie w przestrzeni publicznej, wzajemnie obdarowując się i otrzymując społeczne i estetyczne produkty, często dzięki zapośredniczeniu w długim łańcuchu interakcji. Wytwarza to relacje społeczne jako różnicę - w sensie rozumienia grup i kultur jako odmiennych na skutek wymiany i wzajemnego nakładania się interakcji, co nie występuje we wspólnocie, a tutaj zapobiega wyłączeniu jakiejkolwiek grupy poza społeczeństwo. Społeczne zróżnicowanie miasta dostarcza także pozytywnej niewyczerpalności ludzkich relacji. Zawsze istnieje możliwość zaznajomienia się z nowymi i różnorodnymi ludźmi, posiadającymi odmienne kultury i doświadczenia; istnieje również szansa na uformowanie się nowych grup wokół konkretnych interesów.

Dlatego nieopresyjne miasto definiowane jest przez otwartość wobec niezasymilowanej inności. Oczywiście we współczesnym społeczeństwie nie obserwujemy takiej otwartości na różnicę. Przedstawiam tutaj ideał, który opiera się na polityce różnicy. Zakładając, że zróżnicowanie grup jest dla nas punktem wyjścia życia społecznego, pojawia się pytanie, w jaki sposób relacje między tożsamościami zbiorowymi mają ucieleśniać 
sprawiedliwość, szacunek oraz brak opresji? Współczesne nam związki cechuje raczej rasizm, seksizm, ksenofobia, homofobia, podejrzliwość, szyderstwo. Polityka różnicy daje nam instytucjonalne i ideologiczne narzędzia dla uznawania i utrzymywania różnorodnie definiujących się grup na dwa sposoby: umożliwiając polityczną reprezentację grup o różnych interesach oraz kultywując odmienne kultury i specyficzny charakter grup.

Postulowanie polityki różnicy stawia przed nami wiele pytań. Co definiuje grupę, która zasługuje na uznanie i celebrowanie? W jaki sposób zapewnić reprezentację grupowych interesów, unikając zwykłego pluralizmu liberalnych grup interesów? Jakie instytucjonalne formy mogą zapewnić demokratyczny charakter mediacji miasta oraz reprezentowanych w nim grup $\mathrm{w}$ podejmowaniu decyzji? Te i wiele innych pytań konfrontują nas z ideałem nieopresyjnego miasta. Nie różnią się one od pytań o charakter związków, które powinny panować między wspólnotami. Są to jednak pytania, które odwołanie się do wspólnoty jako ideału życia społecznego zdaje się tłumić lub ignorować. Niektórzy mogą twierdzić, że polityka różnicy w istocie wyraża to, co powinien oddawać ideał wspólnoty, mimo znaczenia przydanego „wspólnocie” przez wielu autorów. Na przykład Fred Dallmayr rezerwuje kategorię wspólnoty na określenie takiej otwartości względem niezasymilowanej inności, odnosząc się do krytykowanych przeze mnie bardziej totalnych związków społecznych w terminach komunalizmu albo ruchu.

W przeciwieństwie do homogeniczności celowo podtrzymywanej w ruchu [the movement], model komunitariański kultywuje różnorodność - jednak bez zachęcania do umyślnej segregacji lub represywnej przewagi jednego ze społecznych podsektorów [...]. Wspólnota może być jedyną formą społecznego zrzeszania, która zastanawia się nad innością i robi miejsce dla niej lub odwrotnej strony subiektywności (i intersubiektywności), a zatem i dla gry różnicy - różnicy między ego i Innym oraz między człowiekiem i naturą ${ }^{35}$.

Ostatecznie kwestią umowy pozostaje, czy nazwiemy tego typu politykę wspólnotą (rozumianą jako grę różnicy). Ze względu na fakt, iż większość artykulacji ideału wspólnoty wyraża dążenie do jedności, które poddałam krytyce, uważam, że czytelniejsze od redefiniowania jego znaczenia byłoby stosowanie odmiennego terminu. Niezależnie od etykietki, na rozwinięcie zasługuje koncepcja społecznych relacji jako ucieleśniających otwartość, szacunek i uznanie względem niezasymilowanej inności. Ponadto radykalna

\footnotetext{
${ }^{35}$ F. Dallmayr, Twilight of Subjectivity..., s. 142-143.
} 
www.praktykateoretyczna.pl

polityka stoi przed wyzwaniem rozwinięcia dyskursu i instytucji, umożliwiających łączenie różnie identyfikujących się grup bez tłumienia, ale i potęgowania różnic.

przełożyła Agnieszka Kowalczyk

Key Words: community, deconstruction, critic of metaphysics of presence, city, difference, Derrida, Adorno, Kristeva. 